\title{
THE BONDAGE TO LIFE, FROM PATOČKA TO CHAKRABARTY
}

MARION BERNARD

\begin{abstract}
The purpose of this article is to question Patočka's relationship between two types of chains for human existence: the vital chains (those of instinct, need, or pressure of individuation) and social chains (those of labour and exploitation). In turn, it is a matter of questioning the conception of the liberation that this relationship underlies. We will attempt to leave open the way to a non-metaphysical interpretation of liberation, no longer as a separation from life, but as a reversal of the direction of life, by resonating the analyses of Jan Patočka with those of Dipesh Chakrabarty, relying on two different figures of the third movement of existence in Patockka: that of sacrifice and that of ritual (which in itself also constitutes a type of sacrifice).
\end{abstract}

Shall we understand freedom as a reconnection to life and the environment, or, on the contrary, as a breach which is the only possibility through which the opening to the world can happen? I shall approach this general issue by the more specific question of the ontological sources of exploitation, as how we are free is strictly correlative of how we are not. Where does exploitation stem from, in Patočka? The interesting point I wish to focus on - interesting from an ecological point of view - is that exploitation seems to lie in the conflict raging between life and existence, or, at the same time, the conflict between the Patočkian figure of the Earth and that of the World. We will especially try to elucidate Patočka's expression "bondage to life", and to understand how Patočka bases social alienation on an ontological alienation which also commands his interpretation of liberation in the three movements of existence. 
My starting point will be a sentence from a text written in 1969 as a supplement to the Second Czech edition of the thesis of 1936: "The Natural World" Remeditated Thirty-Three Years Later, which has been recently translated into English by Erika Abrams. ${ }^{1}$ It is the same text that James Mensch comments on in more detail in "The Motion of Existence", the penultimate chapter of his book entitled Patočka's Asubjective Phenomenology: Toward a New Concept of Human Rights. ${ }^{2}$ The context is a description of the second movement of human existence, namely the movement of reproduction, by which man, when at work, handles things, others and himself just as tools, and which, as Patočka says, increasingly organises, today, both the human world and the surrounding world:

His community with things, his quest into the inside of things shows itself to be simultaneously a way toward his own modification and self-formation. As if man was the work of the primary pressure brought to bear on him by life's bondage to itself and by the possibility of his using and being put to use by his fellows. ${ }^{3}$

Firstly, the "primary pressure" (prvotní tlak) relates here a cosmological phenomenon - the ontological movement of individuation - with the exploitation of nature and men. The exploitation, then, does not seem to refer to a socio-historical accident, but appears as a result of a vital pressure in human individuation. This connection is already underlined by Marx or Arendt, but Patočka reinterprets this motive in the framework of his theory of the three different movements of existence. How does Patockka connect the fact of the exploitation of nature and man with the way he thinks about the cosmological movement of living individuation?

The concept which relates the primordial ontological pressure to the social phenomenon of exploitation is expressed in Czech with "vazba života k sobě"4: Erika Abrams translates the idea of this relation, in French, "l'enchaînement de la vie à elle-même"; in English, "bondage of life to itself". This ideas of pure life, living just for life, or the chains of life appear often in the writings of Patočka, either in the texts about history or about the three movements. But in fact, this

1 Patočka Jan, The Natural World as a Philosophical Problem, Evanston (Illinois), Northwestern University Press, 2016.

2 Mensch James, Patočka's Asubjective Phenomenology: Toward a New Concept of Human Rights, Würzburg, Königshausen \& Neumann, 2016.

3 Patočka Jan, "The Natural World Remeditated Thirty-Three Years Later", in Patočka J., The Natural World as a Philosophical Problem, op. cit., p. 174.

4 See Patočka Jan, "Přirozený svět' v meditaci svého autora po třiatřiceti letech", in Patočka J., Fenomenologické spisy II, Praha, OIKOYMENH, Sebrané spisy Jana Patočky 7, 2009, p. 328. Patočka also sometimes uses the term "odkaz". 
idea, which is used to justify the ontological sources of human exploitation, remains unclear.

First, the difficulty lies in the translation. According to Erika Abrams, ${ }^{5}$ the Czech term used here, "vazba", is fairly neutral and very large (it could mean links, but also bondage, or even detention). As a link, vazba could have the positive connotation as a relation or a union, referring to the synthetic character of life, or to the link between a mother and her child. On the other hand, in the meaning of bondage, it is reduced to a negative connotation: links that no longer connect, but force and alienate.

Actually, it is as if the choice made to have the term translated with "bondage" was overdetermined by the alienating effects of the movement of reproduction. It is indeed tempting to conclude that something of the chains of social exploitation, to use Marx's famous metaphor, is already present in the links of life to itself. Yet, it shall not lead to bypass the problem: how do you move from one ontological link to a social, economic, political chain?

The other can be exploited, turned into a provider on a one-time temporary basis or enduringly and systematically. Man can be put to death. Or, again, life's bondage to itself can be exploited in order to shackle him to the task of mediating with things. ${ }^{6}$

Now, I would like to unfold, step by step, the connection that leads from the internal relation of life to itself, in a neutral sense, to the possibility of exploitation or murder, in order to shed new light on the dynamics of the transition from one movement of existence to another, through a dialectic between bondage and liberation of life. Two issues should be differentiated here: Firstly, how is the relation of life to itself to be understood? And secondly, what binds human existence to this vital link?

\section{Life's Link to Itself, from Patočka to Aristotle}

In what sense is life related to itself? It must be taken into account that Patočka understands life as a movement, drawing on Aristotelian doctrine. Similarly to

5 I thank Erika Abrams for her precious help and comments, given at our meeting at the conference Life and Environment in the Philosophy of Jan Patočka, organized by Karel Novotný in Prague in November 2016.

6 Patočka Jan, The Natural World as a Philosophical Problem, op. cit., p. 173. 
any real movement, life has an internal link, which breathes life into what would otherwise remain dispersed.

According to Patočka, Aristotle's talent lies in restoring the movement in its own intelligibility beyond Parmenides and Plato. Following the doctrine of Aristotle means recognising the existence of an irreducible internal unity, something binding the opposites, a soul by which something can be born and grow. These comments are mostly found in Patočka's lecture on Aristotle.

When a fruit ripens and turns from green to red, or an ignorant man becomes wise, this is not, for Aristotle, a sign of negative change, but instead indicates the passage from power to act - it is the sign of an actualisation that can hold opposites together and make them succeed in the same substrate. The movement possesses the capacity to bind since it is not just mere appearance, but a force that can hold the opposites together: to maintain what is heavy afloat and prevent what is light from rising. Now, this power of life transcends individual borders as it also controls generation or corruption processes, so that the living are bound together, bound to their own past or future, and linked to their environment. On this subject, let me translate one of Patočka's finest texts - being a commentary on Aristotle, it describes a wild rose:

Let us picture a biological process according to this scheme: 'the wild rose grows from a seed, blossoms, bears fruit - year in, year out, until the plant withers and dies. The seed falls into the ground and begins its activity. From the inordinate elements of its environment - black, cold and dry earth; cold and wet water; warm and moist air - it creates, by ordering and transforming, new matter: the soft and green tissue of the stems, which will turn over time into hard, white wood; also by a specific ordering process from the disordered, organs come into being - through which the plant feeds, that is, takes from the surrounding mass and assimilates, adds to its own mass parts of the elemental mixture; nutrition largely calls on condensation and rarefaction processes; all of this brings about that the wild rose, from a little seed, becomes a big plant - (...)'

So, there is something that makes elemental matter forsake its state of disorganization, of its disorder (...) Initially unorganized, it becomes organic (...) The wild rose has carved out/shaped, in the formless continuity of elemental environment, the typical form of a plant. ${ }^{7}$

This binding force of life, which can force an outside element to enter its unifying movement, means that living beings are constantly and concurrently late and

7 Patočka Jan, Aristote, ses devanciers, ses successeurs, Paris, Vrin, pp. 150-152. Translated by M. B. (thanks to Erika Abrams for her re-reading and corrections). 
early with respect to their own schedule, bound by their own becoming and by the becoming of the world, so that they are also linked to each other within a higher order. Yet, this cosmological movement is what Aristotle translates into a hierarchy between beings, or, as Patočka says, into a "quasi-military taxis", which finally enables Aristotle to legitimate human slavery as natural: the telos of naturally inferior beings is to be commanded by superior beings.

On the contrary, no justification of slavery is to be found in Patočka's work, of course. If, as Aristotle argues, exploitation seems inevitable, it is firstly more likely to be due, according to Patočka, to a fault or vacuum than to a necessary order; secondly, it is not exactly based on the same principle: as we will see, for Patočka, exploitation is a result of the unifying link of the movement itself, and not of an external telos.

Ontologically, Patočka disagrees with Aristotle on a fundamental point: he refuses to reduce the movement to ultimately non-dynamic principles, and to reduce the unity of the movement to that of its substrate. Movement is not just an external means or a result for life, but for that specific form of movement, that of the living beings, it is the link of life itself.

Accordingly, Patočka understands the bondage of life differently from Aristotle on several points:

1/ First, he transfers the binding nature of individuation from the cosmological telos to the life link itself, using the image of a circle. It is the "living circle" that replaces the pyramidal order of Aristotle, implying that life never fully vanishes from what it abandons. Patočka writes: "In being born, we have singled ourselves out from the world, from the context of its processes, we have become something

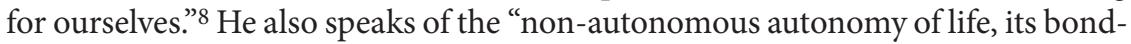
age at once to the other and to itself" 9 - as if the vital circle was the continuous negotiation and renegotiation of an ever-changing inside and outside.

2/ Second divergence with Aristotle: Patočka breaks the ontological continuity between animal movement and human movement. It is no longer controlled by an external ontological hierarchy, but takes the form of a cyclical and without-telos relationship. To describe the gap between the two levels, Patočka uses the image of a vital circle contained within another circle - that of existence:

It is by virtue of corporeality that our existence is, as regards its action too, fully occupied with bodily needs, with the repetition, the restitution, and the extension of its own corporeality. The circle of existence (...) always somehow includes the circle of

8 Patočka Jan, The Natural World as a Philosophical Problem, op. cit., p. 165.

$9 \quad$ Ibid., p. 166. 
life, carrying out vital functions in order for life to return to and into itself - existence is a modification of life that passes from instinctual univocity to practical plurivocity and is no longer concerned only with itself as existent but rather with its mode of being, with the manner in which it realizes its existence. ${ }^{10}$

While James Mensch uses this quotation, ${ }^{11}$ accurately, to insist on the living dimension of existence for Patočka, I would like to focus here on the singularity of the image of the two circles. Although the vital circle remains contained in the circle of existence, it can non longer be said that people are merely living beings related to their environment in the strict sense - they are a movement of questioning of their living being and their inclusion in the world: "this is our way of individuation: being in the world". ${ }^{12}$ But the link between the two circles remains unexplained.

Thus, the transition to the existence level necessarily involves the modification of the vital link. While for the animal, its being is prescribed, for the human being, it is entrusted to it like a task. ${ }^{13}$

\section{The Indirect Link to Life}

At first sight, the source of the movement in the first movement of existence is that the two circles appear confused in a symbiotic and ecstatic relationship to the world. But that original superposition already covers the distance to life. In fact, it is the circle of existence of someone else that contains the newborn life, supports and carries it - it is first in this circle that existence and life merge. In other words, the living fusion in the early days of existence is not without mediation: it is not so much the fusion of existence and life than the fusion of two existences.

The native state of dependence means that the newborn is born incomplete twice: incomplete of the things it needs to incorporate; and incomplete of the beings who could connect it to these things. During pregnancy, when carrying the baby, breastfeeding, and so on, parents or mediators incorporate the environment needed by the child, and so they put both things and themselves at the service of their life.

\footnotetext{
Ibid., p. 163.

Quoted by Mensch James, Patočka’s Asubjective Phenomenology, op. cit., p. 136.

12 Patočka Jan, Le monde naturel et le mouvement de l'existence humaine, Dordrecht, Kluwer Academic Publishers, 1988, p. 112.

13 See Patočka Jan, "Leçons sur la corporéité", in Patočka J., Papiers phénoménologiques, Grenoble, J. Millon, 1995, p. 101.
} 
Correlatively, birth is less a matter of survival than one of compensating for the separation process. Patočka uses in his description of the first movement the expression of "ontological injustice", borrowed from Anaximander, to qualify the irruption of a new being. Thus, the first movement is a problem of keeping the world in balance: the individual must accept being separated, in the same way that the world, under the figure of others, must accept this separation. That is why birth, paradoxically, can only happen insofar as separation is balanced by the process of merging. Individual separation is only possible insofar as it is undone when it happens, "in such a way that all separation and isolation is thereby actively surmounted". 14

Leaving Patočka for a moment, the work of the French anthropologist Pierre Clastres upholds a similar form of this counterbalance idea, in his interpretation of the birth rituals of Guayaki Indians. What impressed him, particularly, was that, from the delivery to the reception of the newborn, everything had to be done in silence, without a single sound being uttered, without a word spoken either by the mother or by her assistants, at risk of death. In Clastres's view, this ritual expresses the fact that in Guayaki cosmology, birth is conceived as a cosmic disorder and provocation, and therefore must be wrapped in silence to be concealed from the rest of the world. Only several days later, once the protective rituals are performed, are Guayaki Indians able to celebrate it with great enthusiasm. In other words, birth only becomes possible afterwards, via an offset or balance ritual.

So, as far as existence, from its very beginning, forms a singular circle that is separate from the one of life: what binds the two circles together? What links the existence to its own life and environment? It is first, according to Patočka, a form of "ruse of being", through the ecstatic and reassuring happiness of the fusion experienced in the satisfaction of our needs.

Everything we do, our each and every function leads back and opens into life; every coming out of ourselves shows the way back, life's movement is a closed curve, and the blissful bonding which assimilates the outside without which we could not live is, in a way, a triumph over the incompleteness of individuation, over our sensed neediness. ${ }^{15}$

But where exactly does this ecstatic happiness come from? If, at first, it could be interpreted as an intrinsically vital pleasure, in reality, the source of this happiness is elsewhere: it lies in the fact that my needs are fulfilled in advance, and for free, by the gift of another existence that represents the world. What links existence to its own life is not life itself, but the fact that it receives it as a gift, that the world

14 Patočka Jan, The Natural World as a Philosophical Problem, op. cit., p. 166.

15 Ibid., p. 166. 
(embodied in the other) offers us our own concern about ourselves - it is first the world that endures in our being. Here is the "ruse of being": "Thus, before itself appearing, being binds us to our own and to an alien being in its singularity and contingency." 16

All in all, it can be said that, in the movement of anchoring, being binds us to the existent in its singularity. The bond used here is the bond of pleasure. The bliss which gives a feeling of unity and fusion in which all things disappear is, paradoxically, what ties life most deeply to itself in its individualized finitude, compensating its incompletion, showing that life has in it an overwhelming, irresistible moment of wholeness, a wholeness in unwholeness, everything in one instant, making up for all want, all separation, and one-sidedness. ${ }^{17}$

This feeling of wholeness, coming from the gift of the world, finds its analogue in the quasi-ecstasy of sacrificial dedication in the third movement.

In the second movement of existence, this dynamic between love and survival is disrupted, because what has been given (and accepted) - namely the link to one's own life and environment - is no longer carried by the existence of others.

Now, this does not mean that the link to life shall become more direct: on the contrary, the second movement is the absolute reign of generalised mediation, in other words, of instrumentality. In particular, man will forge a new and quite paradoxical relationship to their own satisfaction. As long as someone cooks for me, for example, I can focus on the ecstatic pleasure of this meal as a gift. But if I have to cook for myself, it induces another form of satisfaction, more indirect, that, for example, of having been a good cook, or having enjoyed a good meal.

It becomes a deferred satisfaction. To accomplish this movement now means to bear the burden of the satisfying, to be seen, not with the kind and loving eye of acceptance, but rather in a cold appraisal of the way in which we can be put to use. ${ }^{18}$

This new mediation of instrumentality comes from a vacuum. "In performing our ordinary functions, we do not feel that we exist", ${ }^{19}$ as if mere survival could not be a sufficient purpose for the abandoned existence.

\footnotetext{
Ibid., p. 171.

Ibid., p. 170.

Ibid., p. 172.

Ibid., p. 170.
} 
The human being is not attached to its own survival by life itself, but by something extra-individual: the welcoming community in the first movement, the social community of work in the second, the solidarity of the shaken, devoting their lives to each other, in the third movement. Hence this striking fact: while the second movement is supposed to correspond to the reign of the autonomous individual, it generates, on the contrary, an immediate complexity, where the individual is dissolved into the form of an over-organic body. Where is the source of the unity of the second movement? Neither in the substrate, as Aristotle stated, nor in the other, as in the first movement, but everywhere and nowhere at once - in the social. This movement reveals the beings of the world as usable things, correlates, in the words of Patočka, of an "ever more complicated socio-natural body", a "supraorganic organism". ${ }^{20}$ Anonymous society replaces love, organising the exploitation of the world.

Therefore, Patočka considers exploitation as an ontological movement. $\mathrm{He}$ qualifies it as an "originary movement",21 or speaks of the "cheminement de l'exploitation [Genutztwerdens]".22 As a consequence, Patočka concludes that "oppression is necessary":

[The precondition of guilt is] life in a world already full to the brim, where every act of self-assertion necessarily affects others and means virtual damage to them: hence, the necessity of oppression, present not only in its brutal forms but also where it is alleviated. ${ }^{23}$

As a consequence, the dialectics of the movement of existence can only overcome the exploitation and the corresponding dispersion by freeing itself from the bondage to life, by the reversal of the third movement of breakthrough thanks to/ because of a sacrifice.

\section{The Two Different Meanings of "Life in Sacrifice"}

The third movement frees itself from the alienation of work, and that release seems to consist in a release from the link to life. Solidarity replaces exploitation; an extra-worldly orientation replaces the intra-worldly attachment; the unveiling

20 Ibid., p. 174.

21 Patočka Jan, Papiers phénoménologiques, op. cit., p. 136.

22 Ibid.

23 Patočka Jan, The Natural World as a Philosophical Problem, op. cit., p. 174. 
of the world in art or philosophy replaces its reification; openness to the world replaces the submission to the powers of earth and sky. ${ }^{24}$ How to express this breakthrough while keeping the metaphor of the two circles? Patockka wrote that the third movement looks toward life "as free even from itself, (...) free also from death, as infinite". 25 But how is it possible that the circle of existence breaks away from the vital circle?

In this last part of my paper, I would like to question this idea of liberation from life, and the dualism, underlined in particular by R. Barbaras, that on this subject seems to oppose the first two movements to the third one. This opposition between the second and third movement seems problematic for two reasons: Firstly, for an internal reason, as in Patočka's thought itself, this dualism is somehow balanced or contradicted by other statements. Secondly, externally, because the opposition between the second and the third movement does not seem consistent as far as it pretends to describe a general and trans-historical situation. I will argue that it is relevant only for secular societies, which I will try to prove by relying on the studies of Indian postcolonial historian Dipesh Chakrabarty.

I shall begin with the internal reasons for questioning this dualism/tempering this idea of separation from life. First, we have to take into account that the sacrifice is always about life, but on this occasion about the devoted, dedicated, sacrificed life.

The transformation [of the third movement] goes hand in hand with a transformation of what binds me to my own life; it is not mere insight, pure reflection or contemplation (...) Here, too, living in a possibility means grasping and realizing this possibility, it is a mode of praxis. ${ }^{26}$

As James Mensch very accurately points out: human possibilities, even as free possibilities, "are not those of an abstract being-in-the-world, but rather those of our embodied presence within it". ${ }^{27}$ Patockka highlights that the body does not ever disappear: the movement of sacrifice is and remains a bodily movement. Somehow, all his efforts to counter Heidegger, with the theory of the three movements, are nothing but an attempt to think existence through and through as concretely

24 As suggested to us by N. de Warren, we have to keep in mind that Patočka is a reader of Weber, who analyses the historical process of secularisation. His defense of life in sacrifice is somehow to be understood in this framework.

25 Patočka Jan, Le monde naturel et le mouvement de l'existence humaine, op. cit., p. 38.

26 Patočka Jan, The Natural World as a Philosophical Problem, op. cit., p. 175.

27 Mensch James, Patočka's Asubjective Phenomenology, op. cit., p. 137. 
alive, needing to be cared for, forced to work, or also able to devote itself. There is still the problem of what life refers to. Is it still biological life, feeding, breathing, and so on? The fact that, according to Patočka, the great figures who embody sacrifice are Christ and the private in the trenches during World War One certainly reflects its corporeal nature, but refers at the same time to a heroic and exceptional body, remote from the satisfaction of daily needs. It seems then that to a subaltern biological life, mortal, belonging to the earth, whose telos would be to eat or sleep, should be dualistically opposed a higher life, whose extra-worldly telos would be to philosophise, fight, or pray.

Now, my second point: there is yet in his writings a counter-figure of sacrifice, in the context of the mythical sacred worlds. Although Patočka does not develop this sacred figure as such, it could be the basis for an alternative interpretation and subvert the division between the second and third movement. This counter-figure, more mysterious, is that of the ritual. Patočka writes about the third movement:

Already the primitive ritual representational comportment is thus no mere expression, depicting a life-feeling in the relationship of life as a whole to the cosmos as a whole. Rather, it is a change of life, partaking of the marriage of heaven and earth, celebrating their explicit presence and encounter (...). Myth, the ritual representational comportment that accedes to language and takes on narrative form, belongs also to this context. It is nothing other than the same assembly, the same encounter of the world called forth by ritual behavior. ${ }^{28}$

In the ritual, the third movement does not make us leave the Earth, it rather joins the world with a form of radical incarnation - in an ecstasy, which is no longer familial or affective, but ritual and cosmic: a worldwide extension of a living being.

In the last movement, the true movement of existence, the point is to see myself (...) in my 'earthliness', which is, at the same time, a relationship to being and to the universe. ${ }^{29}$

But this ritual counter-figure is subversive, because it is anti-heroic. It invites us to reinterpret the liberation of life in a non-dualistic way. In a transitive sense, life is no longer the object of the liberation, but what frees itself. The separation from life should then be understood in the new sense of the well-known Patočkian

28 Patočka Jan, The Natural World as a Philosophical Problem, op. cit., p. 176.

29 Ibid., p. 175. 
model of the chorismos: not a separation between two things, but the movement of reversal of the intra-worldly orientation. In this "non-metaphysical conception", sacrifice should be what outgrows human life into what it truly is: an emergence from the depth of the world that should be restored to it. In this way, it should be possible to reinterpret the hierarchy in a new anti-heroic sense: not by setting vital activities apart, but by outgrowing and transforming these vital activities in support of devotion.

If Patočka does not think further in that direction, that is because it would involve reversing a partition that he never calls into question: between vital activities and free activities, as it constitutes one of the key oppositions between history and prehistory.

That is why I will now turn to Dipesh Chakrabarty - a post-colonial thinker and historian of labour in India - to question the foundation of this partition between work and sacrifice. A careful and thorough reader of Heidegger, Chakrabarty, in his book Provincializing Europe, ${ }^{30}$ develops a phenomenological study on what Europeans called "the world of work" in Bengali India in the nineteenth century. But in pre- or proto-colonial India, he could not find any work that could be called exclusively intra-worldly. He thus argues that the concept of work itself is only relevant concerning the secular European context, and from then on, untranslatable (or rather irrelevant) in other contexts: in Bengali history, every gesture one might be tempted to identify as "work" refers to ritual acts full to the brim with the sacred, and therefore, calling it "work" is inappropriate. Let us quote Chakrabarty:

God is ever present in the phenomenology of weaving in north India as Pandey explains it (...) Indeed, as Pandey makes clear, work and worship were two inseparable activities to the Julahas, so inseparable, in fact, that one could ask whether it makes sense to ascribe to them the identity that only in the secular and overlapping languages of the census, administration, and sociology becomes the name of their 'occupation': weaving. ${ }^{31}$

Therefore, Chakrabarty explains here that somehow, someone who weaves is not necessarily to be designated as a "weaver".

As Pandey explains, his weavers called themselves nurbaf or 'weavers of light'. (...) Pandey notes 'the intimate connection between work and worship in the lives of

30 Chakrabarty Dipesh, Provincializing Europe: Postcolonial Thought and Historical Difference, Princeton, Princeton University Press, 2000.

$31 \quad$ Ibid., p. 79. 
the weavers, and the centrality of the weavers' major religious text (or kitab), the Mufid-ul-Mominim in the practice of both'. The Mufid-ul-Mominin, Pandey adds, 'relates how the practice of weaving came into the world as its very beginning' (by a version of the Adam, Hawwa (Eve), and Jabril (Gabriel) story), and 'lists nineteen supplicatory prayers to be uttered in the different stages of weaving. During the initiation of novices, notes Pandey, 'all the prayers associated with the loom are recited... The male head-weaver, in whose household this initiation takes place, reads out all of Adam's questions and Jabril's answers from the kitab during the first six days of the month when both the loom and the karkhana (workshop or work loom) are ritually cleaned. When the loom is passed on from father to son, again, 'the entire conversation between Adam and Jabril is read out once by a holy man., ${ }^{32}$

This is merely a first outline to consider of the modification of life differently. We see here that the vital activity of reproduction of life and the sacred orientation toward the higher - or as Patočka sometimes calls it, divine - are not exclusive.

In conclusion, in fact, Patockka is not that far from this idea when he describes, in The Heretical Essays, the "first" mythical worlds as worlds of "integral metaphoricity", "full of gods", or as we could paraphrase, full of the sacred, in terms that seem hardly compatible with his description of the second movement. Obviously, exploitation is not absent from what Patočka calls the mythical worlds - but it appears conditioned, mediatised, included in ritual duties, for example. Now it is clear that when Patockka analyses the opposition between the second and the third movement, it is not the mythical worlds he has in mind. His assumed horizon of description is the specific hybris of the time of the Gestell, as described by Heidegger - he clearly points out a strengthening of the second movement peculiar to our age of increasing technicality, a tendency to organise life more and more, to the accumulation of utensils/devices, to injustice and chaos. Thus, one can say it is the contemporary age that governs the identification of the second movement of existence.

Yet, if for Patočka everything depends on the orientation, as Platonism argued in negative, it should imply that there is no activity that is only vital. If it is possible to devote one's body to prayer or fighting, why should it not be the same for food, or activities satisfying our basic needs - as in ritual offerings? Just as sexuality may for Patočka either reify the body or render it to itself intensely, it should be possible to consider the survival activities not as subordinate - in the sense that they would be inferior, and thus should be reserved to other, inferior people; but as activities that ought to be dedicated or consecrated by rites, re-situated between earth and

32 Ibid., pp. 79-80. 
heaven. "Now, to ask a question before the Earth and the Sky", Patočka writes, "means that one sacrifices oneself so that something else may 'be. (...) Life is not only able to extend itself through self-alienation, but also to transubstantiate itself thanks to dedication". ${ }^{33}$

When Patočka reserves this transubstantiation for activities of what one might call a "higher" corporeality, he seems to be hostage to the historically abstract division he draws between the movement of work and the movement of breakthrough, specific to secular societies. In so doing, his conception of sacrifice could paradoxically be qualified as secularised. By absolutising a historical situation, he confuses two ideas of freedom - one subversive, with its roots in negative Platonism; another, dualist, stemming from his phenomenology of history, and opposing the mythical belonging or bondage to living nature to the historical relationship to the world.

We have thus tried to unravel, in the Patočkian conception of life, the place where an ultimate form of dualism is deeply entrenched. It seems that his phenomenology of movement, if continued to its logical conclusion, should on the contrary lead to the reversal of the hierarchy of the three movements towards each other, in favour of a primacy of the orientation of every living movement, even of the simplest one, towards the particular being or towards the totality.

Marion Bernard is research fellow at the Husserl Archives of Paris. An alumnus of the Ecole Normale Supérieure in Paris and a student of Renaud Barbaras, she focuses her academic work on phenomenology, especially Jan Patočka. Her main publication is Patocka et l'unité polémique du monde, Peeters Publishers, coll. Bibliothèque philosophique de Louvain, 2016.

E-mail: mnbernard@gmail.com

33 Patočka Jan, Le monde naturel et le mouvement de l'existence humaine, op. cit., p. 45. 